\title{
Development of Low-Cost High-Power Sinusoidal Function Generator for Driving a Single Tone Wave into Speaker using Arduino Uno and 2N3055
}

\author{
Adimas Wicaksana* and Sulanjari \\ Mechanical Engineering, Faculty of Engineering, Universitas Pamulang \\ Jl. Surya Kencana No. 1 Pamulang, Tangerang Selatan, Banten 15417, Indonesia \\ E-mail: *dosen01678@unpam.ac.id
}

Masuk:21 Agustus 2018 Direvisi:26 September 2018 Disetujui :7 Januari 2019

\begin{abstract}
Function generator is one of the most important equipment in electronics testing. However its cost can be quite prohibitive. In this work we describe how to transform a square wave generated by Arduino into a sine wave by using filter/amplifier based on $2 \mathrm{~N} 3055$, thus enabling low-cost high-power function generator. The electronics circuit was assembled using AWG22 wire and breadboard. Said function generator will be shown to be capable of producing sine wave with frequency between $500 \mathrm{~Hz}-10 \mathrm{KHz}$. With proper tuning it is capable of achieving up to $0.6 \%$ accuracy within the desired value. It costs less than IDR 150000 and capable of delivering $100 \mathrm{~W}$ of power.
\end{abstract}

Keywords: Arduino, function generator, 2N3055

\begin{abstract}
Abstrak: Function generator adalah salah satu alat paling penting untuk pengujian elektronik. Sayangnya biaya pembelian alat tersebut cukup mahal. Pada penelitian ini kami akan mempelajari cara mengubah gelombang kotak yang dihasilkan oleh Arduino menjadi gelombang sinus dengan menggunakan filter/amplifier berbasis $2 N 3055$ sehingga dapat menghasilkan function generator berdaya tinggi dengan biaya rendah. Function generator tersebut mampu menghasilkan gelombang dengan frekuensi antara $500 \mathrm{~Hz}-10 \mathrm{khZ}$. Dengan prosedur penyeteman yang benar function generator ini dapat menghasilkan akurasi sampai dengan 0,6\% dari angka yang ingin dicapai.
\end{abstract}

Kata kunci: Arduino, function generator, 2N3055

\section{INTRODUCTION}

Function generator plays a crucial role in electronics laboratory. It can be used to test the performance of an amplifier or measure the value of an unknown capacitor/inductor. The price of a commercial function generator, however, can be quite expensive. It can cost well above IDR 1000000 for a single function generator. While there are a single board solutions that cost less sometime one can't spare money to justify the purchase of an equipment whose sole function is to generate waveform.

On the other hand, an Arduino is a general purpose tool. A typical Arduino Uno costs around IDR 50000. After adding all the passive (inductor, capacitors) and active (2N3055) components the typical cost of equipment described in this paper is still lower than IDR 150000. This means that it is still quite competitive with respect to other single board solution that can be found online whose price ranges from IDR 75000IDR200000. On top of that it can be reused for different purpose such as data acquisition[1] and speed control system [2]. 


\section{THEORY}

The problem with Arduino is that it is only capable of producing digital output which means that it is unable to produce a sinusoidal output. Nevertheless since Arduino can produce square wave and a square wave can be represented as summation of sinusoidal waves[3] one can generate a sinusoidal wave simply by filtering the higher harmonics. The summation can be described in the form of a picture as shown in Figure 1.

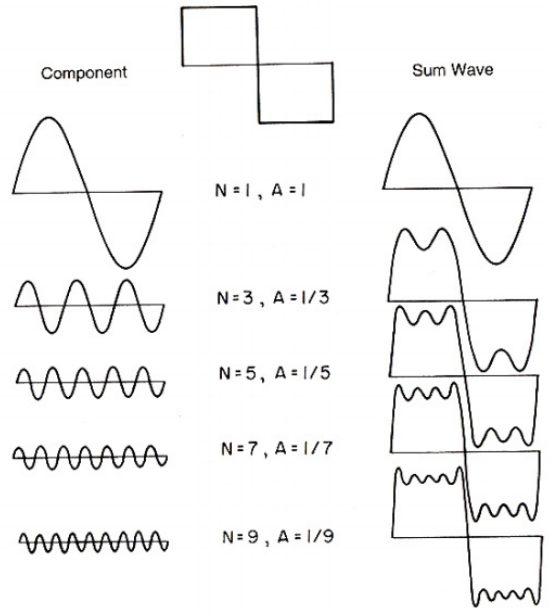

Figure 1. Square Wave as A Summation of Sine Wave [3]

To achieve this an L-C filter can be utilized in conjunction with 2 N3055. Besides acting as a filter this particular circuit also serves as a class $\mathrm{C}$ power amplifier that is suitable for sine wave generator[4]. The amplifier is necessary because the original square wave signal is not quite strong enough to drive the speaker. Conceptually the function generator can be shown as in figure 2 below:

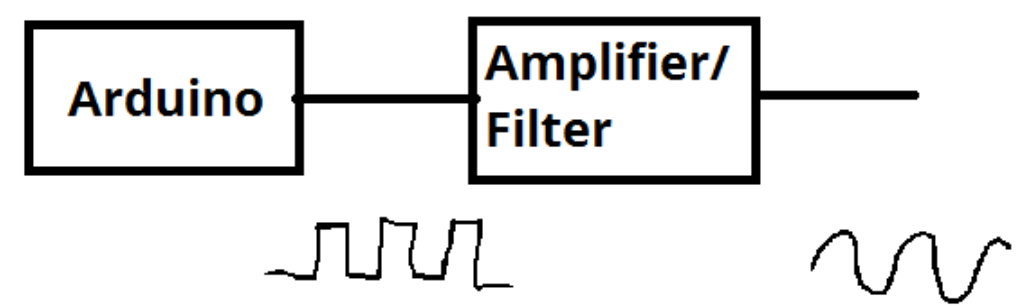

Figure 2. Conceptual Block Diagram

IC 2 N3055 is chosen for its ability to drive relatively higher current[5]. This is also the reason why it is quite popular for high power application such as electricity generator[6] and high voltage DC power supply[7]. It is also capable of operating at higher power $(>100 \mathrm{~W})[8]$.

\section{METHODS}

Arduino was first programmed using Arduino IDE (Integrated Development Environment) version 1.8.5 with a simple program that generates square wave. The program consists of 4 steps:

1. Drive the output pin into high(5V) state

2. Delay for $T / 2$ seconds using delayMicrosecond function where $T$ is the desired period of the waveform

3. Drive the output pin into low $(0 \mathrm{~V})$ state

4. Delay for $\mathrm{T} / 2$ seconds using delayMicrosecond function and go back to step 1

These steps can be translated into $\mathrm{C}$ program shown in figure 3. 


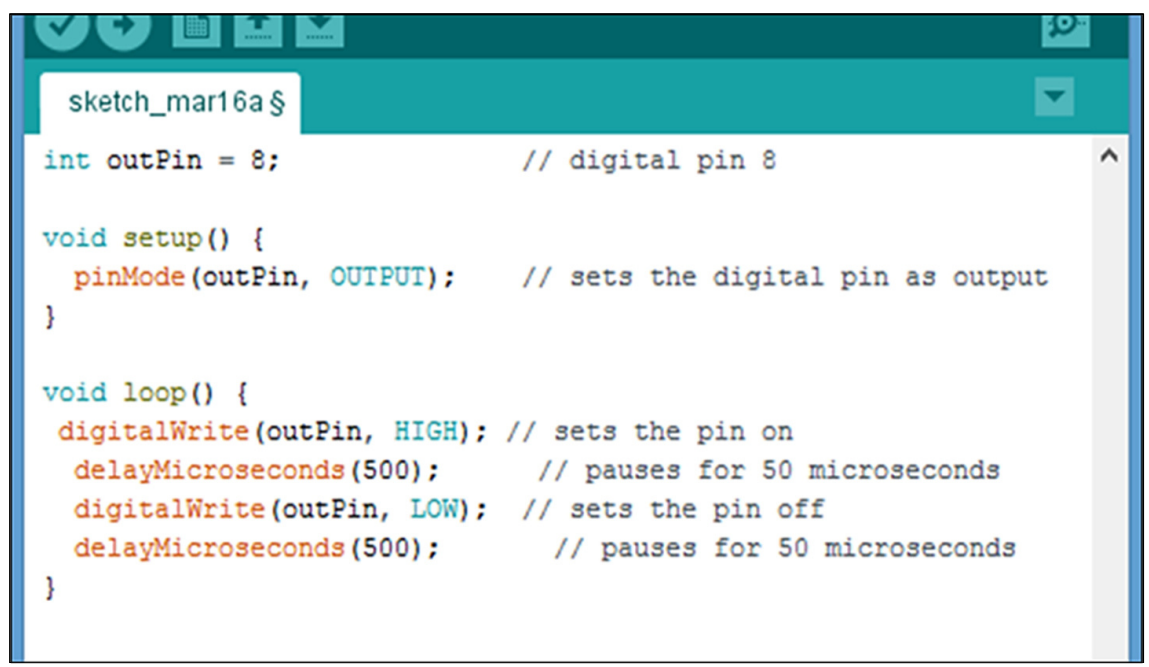

Figure 3. Arduino Program Used to Generate Square Wave

Since the transition from state 0 to state 1 and vice versa would be abrupt the generated waveform would be a square. The wave would need to be filtered using L-C filter inside class $\mathrm{C}$ power amplifier. Below are the schematics:

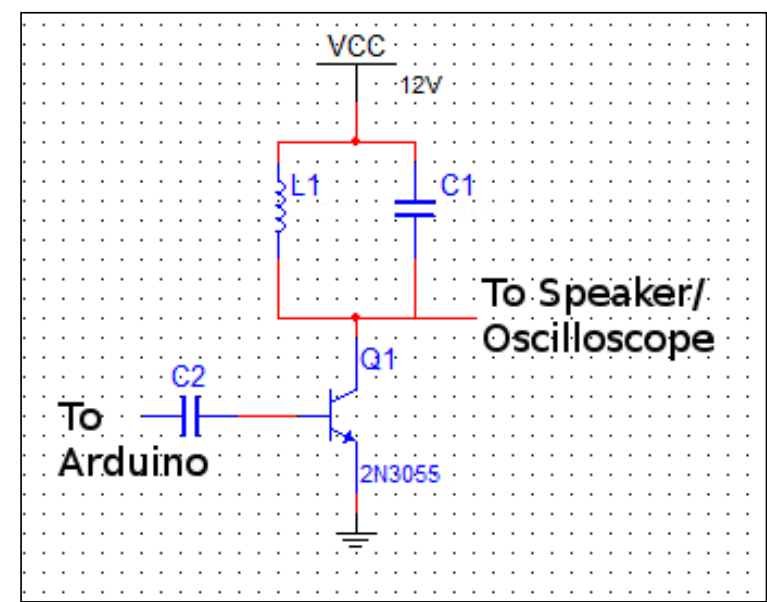

Figure 4. Schematics of the Filter/Amplifier

If gain control is deemed necessary a potentiometer can be added between the base and ground. An L-C bandpass filter has a peak frequency of [9]

$$
f=\frac{1}{2 \pi \sqrt[2]{L C}}
$$

Since the value of capacitor tends to be very low (pf-nf) and the required frequency is relatively low (between $500 \mathrm{~Hz}$ and $10 \mathrm{KHz}$ ) the value of inductor is selected to be as high as possible, in this case $0,25 \mathrm{H}$. The value of capacitor vary from $1 \mathrm{nf}$ to $300 \mathrm{nf}$ depending on the desired frequency. A bypass capacitor is placed between the base and the emitter to act as a first stage low pass filter. The value is between 100pf and 10uf depending on the required frequency. Below are the values L1,C1, and C2 for each frequency tested: 
4 | Adimas Wicaksana dkk., Development of Low-Cost High-Power Sinusoidal....,

Table 1. Design Parameter for Each Frequency Tested

\begin{tabular}{ccccc}
\hline Frequency $(\mathrm{Hz})$ & $\mathrm{L} 1(\mathrm{H})$ & $\mathrm{C} 1(\mathrm{nF})$ & $\mathrm{C} 2(\mathrm{nF})$ & Arduino Delay $(\mu \mathrm{s})$ \\
\hline 581 & 0.25 & 300 & 1000 & 860 \\
711 & 0.25 & 200 & 700 & 702 \\
1000 & 0.25 & 100 & 300 & 500 \\
10000 & 0.25 & 1 & 0.1 & 50 \\
\hline
\end{tabular}

The electronic circuit described in figure above was then placed onto a breadboard. All connection in the breadboard was made using 22AWG cable. End connection to Arduino was made using standard 22AWG cable using as well. The other end was connected to either speaker or oscilloscope using alligator clip based on which test was performed.

In this study two kinds of tests were performed to judge the performance of the function generator. In the first test oscilloscope was used to observe generated wave visually. In the second test the function generator was connected to a speaker whose output was then captured using microphone. The audio output can then be analyzed by a computer using Spectralab FFT software.

The followings are the Bill of Materials of all the components used in producing the square wave

Table 2. Bill of Material of Components Required

\begin{tabular}{lc}
\hline \multicolumn{1}{c}{ Components } & \multicolumn{1}{c}{ Cost } \\
\hline Arduino & IDR 50,000 \\
Inductor $0.25 \mathrm{H}$ & IDR 55,000 \\
2N3055 & IDR 10,000 \\
Others(Capacitor, & IDR 20,000 \\
Breadboard, Wires) & \\
\hline Total & IDR 140,000 \\
\hline
\end{tabular}

\section{RESULT AND DISCUSSION}

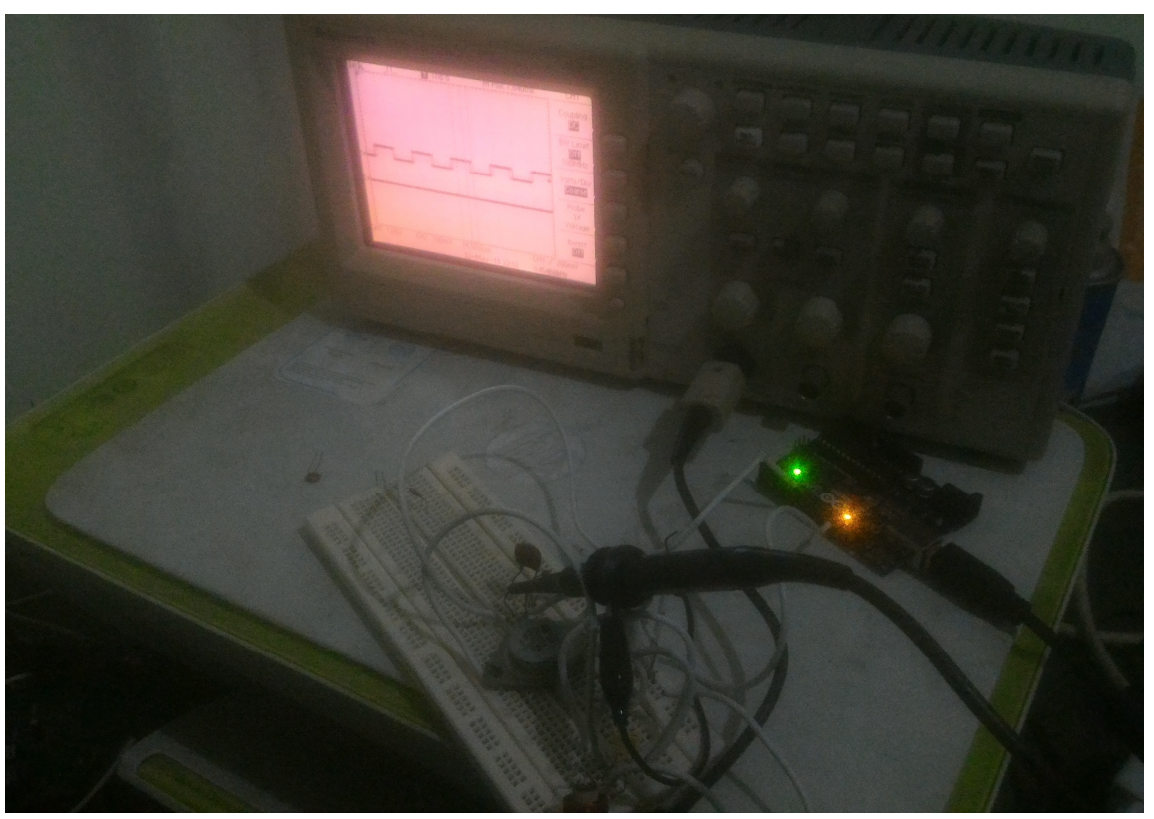

Figure 5. Square Wave Output from Arduino @ $10 \mathrm{KHz}$

From Figure 5 we can see that the output generated from Arduino is a square wave and needs to be filtered further. 


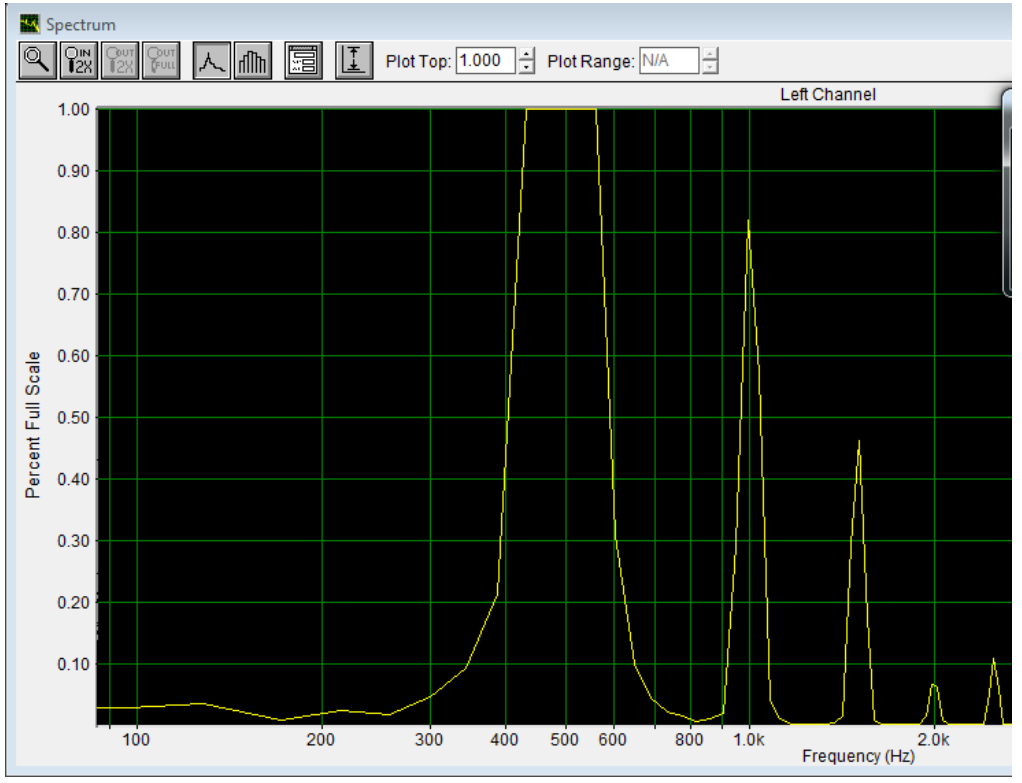

Figure 6. Square Wave Output from Arduino @ $500 \mathrm{~Hz}$

Figure 6 shows that SpectraLab FFT also shows higher harmonics at multiples of fundamental frequency, which is expected.

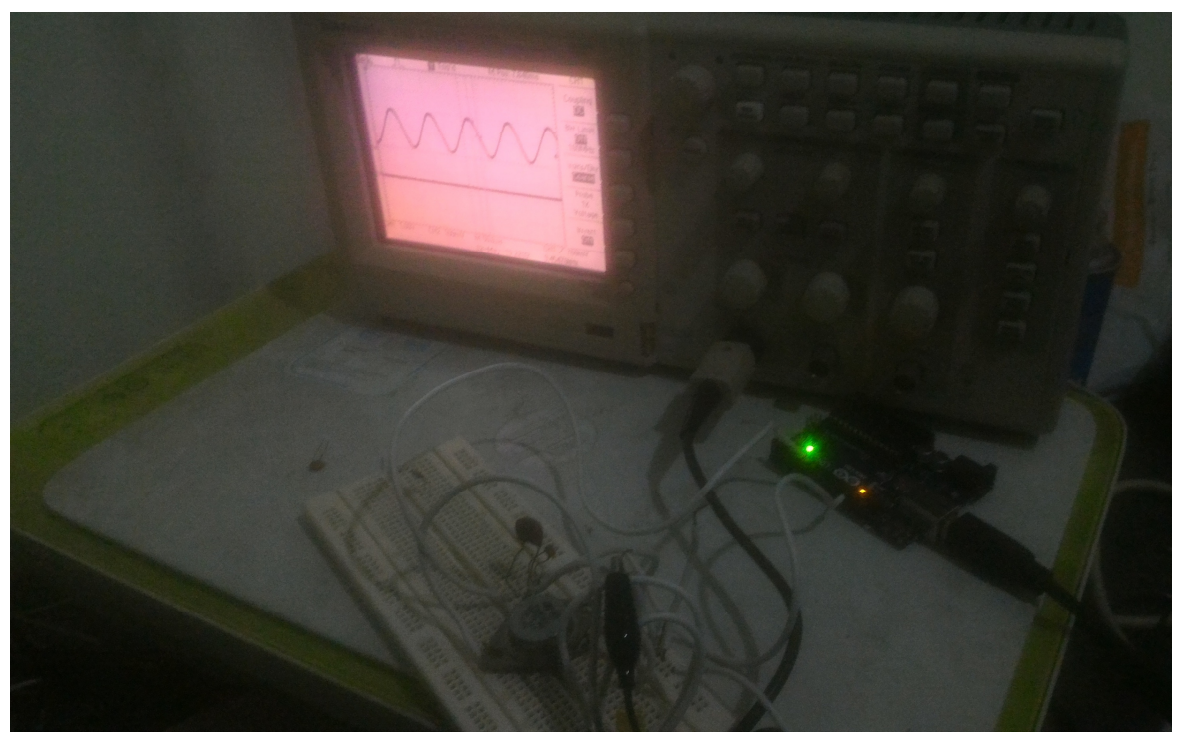

Figure 7. Sine Wave Output from Filter/Amplifier @10KHz

After filtering the output generated is a sine wave. Also notice the higher voltage due to the amplifier. 
6 | Adimas Wicaksana dkk., Development of Low-Cost High-Power Sinusoidal....,

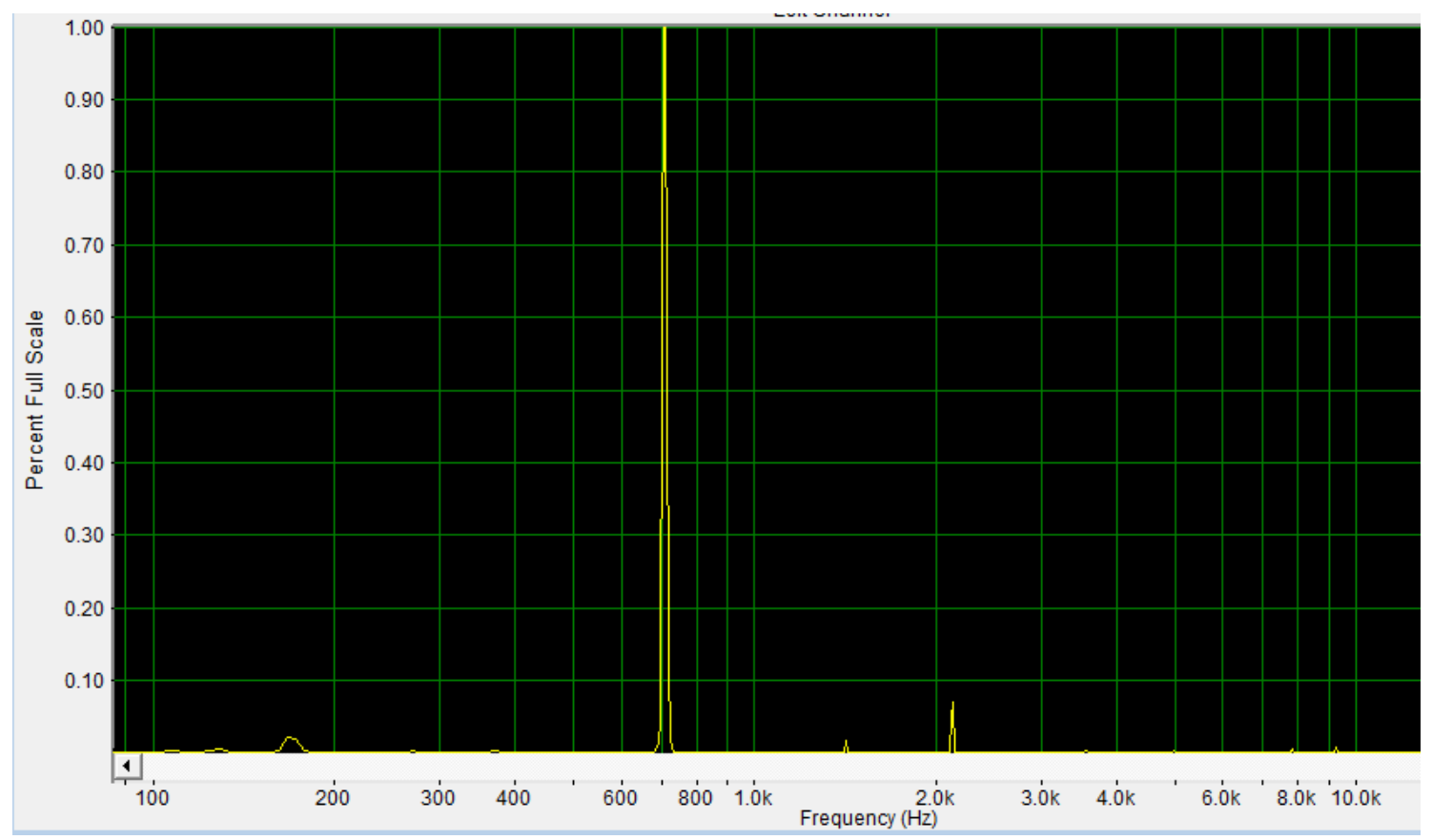

Figure 8. Spectrum Analysis after Filtering @ $700 \mathrm{~Hz}$

Figure 8 shows that output from SpectraLab FFT also shows significantly lower magnitude of higher harmonics.

Another observation noted was that the peak frequency detected by SpectraLab FFT is not exactly the same as the one programmed into Arduino. The frequency measured is typically around $1-3 \%$ lower than what is programmed. This is because there are certain overhead unaccounted for like the time required to set-up all the registers and the time required to jump inside the loop.

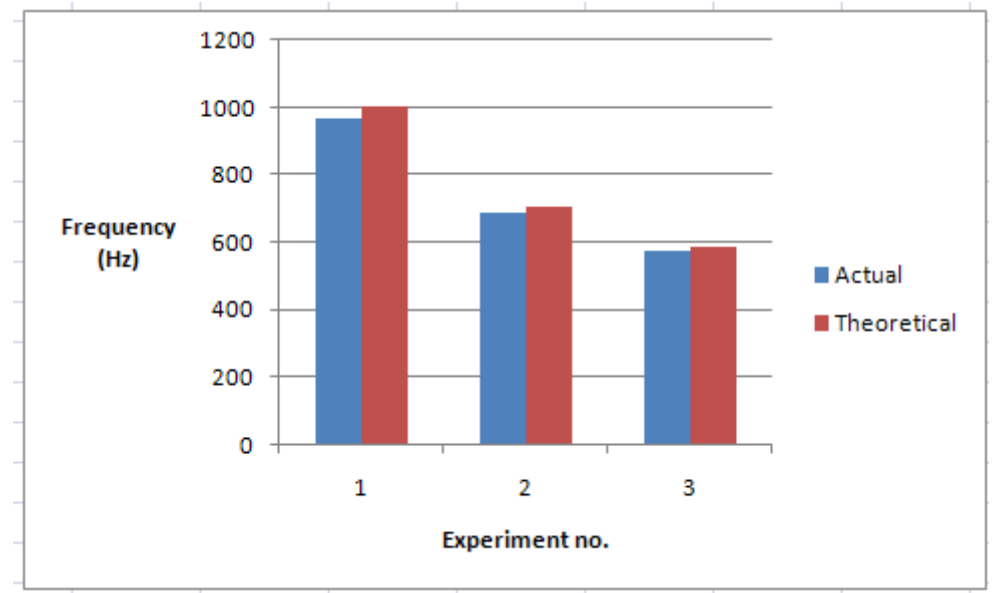

Figure 9. Lower Actual Frequency as Compared to Theoretical Ones

To compensate for this one can simply lower down the programmed delay so that the produced wave has the exact same frequency as designed. Figure 10 shows that we can achieve $0.6 \%$ accuracy for $1 \mathrm{KHz}$ frequency by changing Arduino delay value from 500 to 491. 


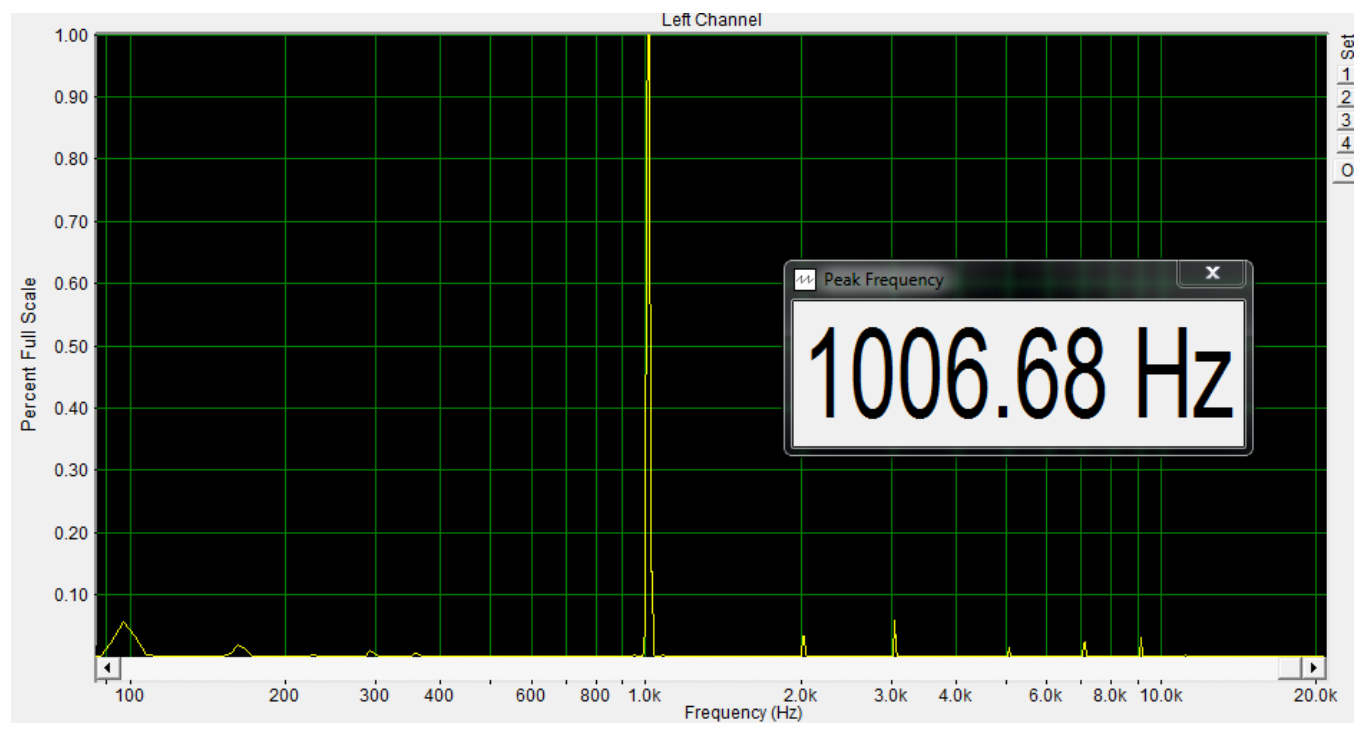

Figure 10. Accuracy of $0.6 \%$ Achieved @ $1 \mathrm{KHz}$

\section{CONCLUSIONS}

A sine wave generator has been developed using Arduino and 2N3055-based class C Power Amplifier. The total cost required to produce this generator is less than IDR 140,000 and it is capable of driving around $100 \mathrm{~W}$ of power. This function generator has been proven capable of producing output between $500 \mathrm{~Hz}$ and $10 \mathrm{KHz}$. While there can be discrepancy between the designed frequency and the actual frequency rendered this issue can be corrected simply by programming the Arduino at lower frequency.

\section{REFERENCE}

[1] Yohan, Astuti F and Wicaksana A 2018 J. Chimica et Nat. Acta. 6(3) 111

[2] Rai N and Rai B 2013 Int. J. of Engineering Trends and Technology 4(2) 137

[3] Berg R E and Stork D G 2005 The Physics of Sound (San Fransisco:Pearson)

[4] Smith J R 1997 Modern Communication Circuits (Singapore:McGraw-Hill)

[5] Ellis J N and Osadchy V S 2001 IEEE Transactions on Electron Devices 48(11) 2477

[6] Maysha I, Trisno B and Hasbullah 2013 Electrans 12(2) 89

[7] Deb R and Sarma D K 2016 Bulletin of Phys. Proj. 129

[8] On Semiconductor 2005 2N3055(NPN), MJ2955(PNP) Complementary Silicon Power Transistors. (Arizona:SCILLC).

[9] Odyniec M 2002 RF and Microwave Oscillator Design (Boston:Artech House)

[10] Arduino LLC 2018 Arduino Language Reference https://www.arduino.cc/reference/en/ 